\title{
The National-Level Energy Ladder and its Carbon Implications
}

\author{
Paul J. Burke \\ Crawford School of Economics and Government, Australian National University
}

CCEP working paper 1116, November 2011

\begin{abstract}
This paper documents an energy ladder that nations ascend as their per capita incomes increase. On average, economic development results in an overall substitution from the use of biomass to fulfill energy needs to energy sourced from fossil fuels, and then toward nuclear power and certain low-carbon modern renewables such as wind power. The results imply an inverse- $U$ shaped relationship between per capita income and the carbon intensity of energy, which is borne out in the data. Fossil fuel-poor countries are more likely to climb to the upper rungs of the national-level energy ladder and experience reductions in the carbon intensity of energy as they develop than fossil fuelrich countries. Leapfrogging to low-carbon energy sources on the upper rungs of the national-level energy ladder is one route via which developing countries can reduce the magnitudes of their expected upswings in carbon dioxide emissions.
\end{abstract}

Centre for Climate Economics \& Policy

Crawford School of Economics and Government

The Australian National University

ccep.anu.edu.au

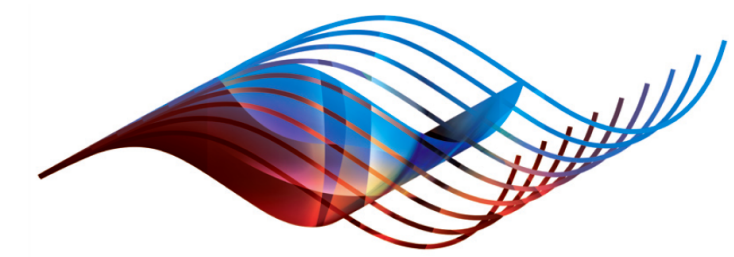

CLIMATE

Economics \& Policy 
The Centre for Climate Economics \& Policy (ccep.anu.edu.au) is an organized research unit at the Crawford School of Economics and Government, The Australian National University. The working paper series is intended to facilitate academic and policy discussion, and the views expressed in working papers are those of the authors. Contact for the Centre: Dr Frank Jotzo, frank.jotzo@anu.edu.au.

Citation for this paper:

Burke, P. J. (2011) The national-level energy ladder and its carbon implications CCEP Working Paper 1116, Centre for Climate Economics \& Policy, Crawford School of Economics and Government, The Australian National University, Canberra. 


\title{
The national-level energy ladder and its carbon implications
}

\author{
Paul J. Burke \\ Crawford School of Economics \& Government, Australian National University, Canberra, \\ ACT 0200, Australia \\ E-mail: paul.j.burke@anu.edu.au \\ Telephone: +61261256566
}

Fax: +61261253700

October 2011

\begin{abstract}
This paper documents an energy ladder that nations ascend as their per capita incomes increase. On average, economic development results in an overall substitution from the use of biomass to fulfill energy needs to energy sourced from fossil fuels, and then toward nuclear power and certain low-carbon modern renewables such as wind power. The results imply an inverse-U shaped relationship between per capita income and the carbon intensity of energy, which is borne out in the data. Fossil fuel-poor countries are more likely to climb to the upper rungs of the national-level energy ladder and experience reductions in the carbon intensity of energy as they develop than fossil fuel-rich countries. Leapfrogging to low-carbon energy sources on the upper rungs of the national-level energy ladder is one route via which developing countries can reduce the magnitudes of their expected upswings in carbon dioxide emissions.
\end{abstract}

JEL codes: O11, O13, Q43; Q54

Keywords: Carbon dioxide emissions; Economic development; Energy mix; Energy ladder; Substitution; Transition

\section{Acknowledgements}

I am grateful for comments from Guy Dundas, David Stern, and attendees at the Australian Agricultural and Resource Economics Society 55th Annual Conference, the 29th United States Association for Energy Economics/International Association for Energy Economics North American Conference, and seminars at the Australian National University, La Trobe University, and the University of Sydney. 


\section{Introduction}

Energy is at the core of the global economy, and emissions of greenhouse gases from energy use are the principal contemporary contributor to human-induced climate change. Yet little formal quantitative evidence exists on how the energy mix evolves as a country experiences sustained economic growth, and why it evolves in different ways in countries with different resource endowments. This paper uses cross-sectional and panel data for a sample of 132 countries over the period 1960-2005 to explore the effect of increasing per capita incomes on the overall energy mix.

The findings point to the existence of an "energy ladder" that countries climb as they develop. Low-income countries are heavily reliant on biomass to meet their energy needs (so biomass is on the first rung of the national-level energy ladder). These countries increasingly substitute toward fossil fuels and some hydroelectricity as they emerge from low-income status (so hydro and fossil fuels are middle-rung energy sources). As they do so, they do not fully transition away from biomass use, but the share of biomass in a nation's energy bundle tends to fall to a low level. At higher income levels still, countries typically become less reliant on hydroelectricity, oil and coal, while continuing to expand their dependence on natural gas and increasingly adopting capital-intensive energy sources such as nuclear power and modern renewables (e.g. wind). Nuclear power and modern renewables are thus on the upper rungs of the national-level energy ladder. Energy endowments affect the extent to which countries climb the national-level energy ladder as their incomes increase: countries with large endowments of any particular energy type are less likely to continue climbing to energy sources on higher rungs of the national-level energy ladder. 
That economic development typically results in an initial substitution toward fossil fuels and then a later substitution away from the most carbon-intensive fossil fuels (coal and oil) implies an inverse-U relationship between gross domestic product (GDP) per capita and the carbon intensity of energy. The existence of this inverse $U$ is confirmed using both the crosssectional and panel datasets. Thus while there is no robust evidence of a general environmental Kuznets curve (EKC) for per capita carbon dioxide $\left(\mathrm{CO}_{2}\right)$ emissions for the global sample, the results provide strong evidence that economic development leads to a carbonization and then eventual decarbonization of energy as countries ascend the nationallevel energy ladder. The decarbonization of energy at high income levels is particularly pronounced in countries with few domestic fossil fuel endowments, as fossil fuel-poor countries are the most likely to climb to the low-carbon upper rungs of the national-level energy ladder (nuclear power and modern renewables). The national-level energy ladder provides an alternative conceptual model for understanding the income- $\mathrm{CO}_{2}$ emissions relationship, and one that incorporates direct consideration of causal mechanisms (energy transitions) and underlying sources of heterogeneity (resource endowments).

The remainder of this paper is organized as follows. Section 2 discusses initial evidence on energy and economic development. Section 3 discusses reasons for the existence of a national-level energy ladder. Section 4 discusses the econometric estimation method and the data to be used. The results are presented in Section 5. An application of the results to explain how the carbon intensity of energy evolves as economies develop is presented in Section 6. The final section concludes. 


\section{Energy and economic development: Initial evidence}

A number of studies have focused on the determinants of the mix of energy sources used at the household level (e.g. Hosier and Dowd, 1987; Heltberg, 2004; Hosier, 2004). These studies support the existence of a household-level energy ladder that households climb as their incomes increase. The process sees households substitute from local fuels such as biomass to transition fuels such as kerosene and coal, and then to modern sources of energy such as liquefied petroleum gas, natural gas, and electricity. This paper applies the concept of the household energy ladder to the evolution of energy sources at the national level.

At the macro level, a group of authors (Grübler, 2004; Bashmakov, 2007; Marcotullio and Schulz, 2007) provide descriptive evidence on the aggregate energy transitions that are commonly experienced as economies develop. As far as I am aware, however, there is no existing quantification of the relationship between per capita GDP and the national energy mix for a global sample.

There is recent evidence on how the electricity mix evolves as economies develop. Using a large panel dataset, Burke (2010) finds that countries typically transition from hydroelectricity and oil-fired electricity toward coal, natural gas, and then nuclear power and non-hydro renewables such as wind power, for their electricity needs as they develop. That paper also finds that domestic energy endowments are important in explaining how far up the "electricity ladder" countries climb as their per capita incomes increase. The current paper analyses total energy use rather than only electricity generation, and so is broader in scope than Burke (2010). (Only around 40\% of the world's energy is used for electricity generation; IEA, 2007a.) Results on the national-level energy ladder also differ to those for the electricity ladder in important ways (particularly with respect to biomass). This paper also includes an 
extension of the results to explain the existence of a non-linear relationship between per capita income and the carbon intensity of energy.

The energy mixes of low-, middle-, and high-income countries for the year 2005 are presented in Table 1. The energy sources are ordered along the rungs of a general national-level energy ladder. Low-income countries source slightly more than half of their energy from biomass, and around $46 \%$ from fossil fuels. In contrast, middle-income countries source more than four-fifths of their energy from fossil fuels, primarily coal and oil. High-income countries also source a large share of their energy from fossil fuels, but tend to be less dependent on coal than middle-income countries. High-income countries also source a larger share of their energy from nuclear power, and a growing share from renewables such as waste and wind. The hydro share of the energy mix tends to be lower for countries with higher incomes.

-Table 1 here-

\section{Potential reasons for a national-level energy ladder}

A national-level energy ladder may emerge as a result of several sets of factors. The first of these is supply-side factors, as represented in the models of Tahvonen and Salo (2001) and Burke (2010). The existence of diminishing returns to domestic energy resources (e.g. running out of rivers to dam for hydroelectricity) means that imported fuels or modern energy sources such as nuclear power become increasingly cost-competitive relative to domestic energy options as incomes increase and more domestic resources are exploited (and/or depleted). Economic development also relieves capital, human capital, and institutional constraints, meaning that energy sources that are capital intensive and/or require advanced 
human capital or energy sector institutions, such as nuclear power and wind power, become increasingly viable as economies develop.

A national-level energy ladder may also emerge due to a positive income elasticity of demand for energy forms that are more effective, efficient, convenient, safer, and/or cleaner (Grübler, 2004). Consequently, higher incomes likely see a reorientation of demand away from locallycollected biomass (which tends to be an inconvenient, labour-intensive, locally-polluting energy form) toward demand for high-quality energy forms such as electricity and petroleum. At the national level, increased incomes may also lead to a shift in demand toward higherquality energy forms, such as those which are less polluting or allow enhanced energy security. In (high-income) France and Denmark, for instance, governments supported transitions to nuclear and wind power (respectively) in response to energy security and environmental issues associated with the use of fossil fuels (Hadjilambrinos, 2000).

A national-level energy ladder may also emerge as a result of structural change. Economic development typically sees a realignment of economic activity (and energy demand) from agriculture toward industry, transport, and services, although the relative importance of industrial activity tends to fall at high income levels (Judson et al., 1999; Medlock and Soligo, 2001; Schäfer, 2005). Given that sectoral energy demand is often tied to specific forms of energy, structural change as an economy develops may result in changes in the energy mix. The ascendance of the transportation sector as economies develop, for instance, likely places upward pressure on the oil share of the energy mix.

Other features of economic development, such as urbanization, may also contribute to the national-level energy ladder. Urban populations are less likely to be able to collect plant 
matter to use for heating and cooking purposes due to a lack of proximity to forests and farms, meaning that it should be expected that urbanization reduces overall dependence on biomass energy (Barnes and Floor, 1999). Urban areas are also more likely to be connected to energy grids (e.g. for electricity and natural gas) given their higher population densities. The shift to urban living as economies develop may thus contribute to a switching from the use of primary biomass toward electricity and natural gas.

\section{Estimation approach and data}

The model for estimating the income effect on the energy mix is of the form:

$$
S_{j, c, t}=\alpha_{j} \ln Y_{c, t}+\beta_{j}\left(\ln Y_{c, t}\right)^{2}+\mathbf{x}_{c, t}^{\prime} \chi_{j}+\varepsilon_{j, c, t}
$$

where the dependent variable is the percentage share of primary energy source $(S)$ type $j$ in total energy use in country $c$ in year $t, Y_{c, t}$ is real GDP per capita in purchasing power parity (PPP) terms, and $\mathbf{x}_{c, t}^{\prime}$ is a vector of additional potential determinants of the energy mix. $\varepsilon_{j, c, t}$ is an error term, with $E\left(\varepsilon_{j, c, t}\right)=0$. The vector includes variables measuring country size (the natural logarithms of population and land area), a dummy for transition economies (which tended to have a large focus on industrial energy pre-transition), and proxies for domestic energy endowments. The endowment variables include per capita: a) forest area (as a proxy for biomass potential); b) renewable internal freshwater resources (as a proxy for hydro power potential); c) oil reserves; d) coal reserves; e) natural gas reserves; and f) volcanoes (as a proxy for geothermal potential). I do not explicitly control for policy variables or withincountry energy prices as these are likely to be functions of underlying factors such as development level and resource endowments. Results on the income effect on the energy mix are similar in estimations that control for ratification of the Kyoto Protocol or regional fixed effects (which partly capture cultural, climatic, and other differences between countries). 
Estimations are carried out for separate dependent variables measuring the shares of each of the nine energy source types in Table 1 in total primary energy supply (TPES). These nine sources together accounted for $99.8 \%$ of measured global TPES in 2005. (Results for a tenth source, "other", are not shown.) I present ordinary least squares estimates for the crosssectional sample and estimates using both the between estimator and the fixed effects estimator (with year dummies) for the panel sample. (Unreported results using the random effects estimator are similar to those using the fixed effects estimator.) Standard errors are robust to heteroscedasticity.

Important features of the estimation approach are that it involves the use of fractional data for the dependent variable and that the estimation equations are subject to a cross-equation aggregation restriction (the dependent variables for the ten equations sum to 100). Overall results are similar in specifications that explicitly recognize one or both of these characteristics of the data, such as compositional data analysis models, fractional logit models, zero/one inflated beta models, or fractional multinomial logit models. Results are also similar in Tobit models, or in logit or probit estimations (either standard or ordered). Tobit models are not suited to the inclusion of country fixed effects, but the panel data results are similar in estimates using Honoré's (1992) semiparametric model. Results for these specifications are available from the author on request. Because the same set of controls is included in each equation, seemingly unrelated regressions estimation provides no advantage over equation-by-equation ordinary least squares.

Results are presented for specifications both with and without the quadratic term. For the quadratic estimates, GDP per capita levels at the implied turning points are shown. The 
estimated relationships are only classed as non-monotonic ( $U$ or inverse- $U$ shaped) if the quadratic term is statistically significant at the $10 \%$ level or higher and the GDP per capita level at the estimated turning point is between 2005 I $\$ 3,000$ and the year-2005 sample maximum GDP per capita level. ${ }^{1}$

Estimations are presented for a cross-section of 132 countries for the year 2005, and a panel of 4,337 observations for the same countries for the period 1960-2005. The vector of controls $\mathbf{x}_{c, t}^{\prime}$ is not included in the panel estimations due to a lack of time-series data for the endowments variables. The countries in the sample together made up more than $95 \%$ of the global population in 2005. The choice of 2005 for the cross-sectional estimations is of no particular consequence, as results are similar for other years.

Energy data are from the International Energy Agency (IEA) (2007a, 2007b). The IEA energy data are the best available for the current purpose, but particular concerns are held regarding the accuracy of the data on biomass use, which may be underreported. It is nevertheless believed that measurement error is unlikely to have any important qualitative impact on the results presented in this paper, even if the transition from biomass is potentially underestimated. A list of definitions and data sources is provided in the Appendix.

\footnotetext{
${ }^{1}$ Very low turning point estimates are often a by-product of curvature at high income levels and are frequently unrepresentative of energy mix-income relationships at the left tail of the GDP per capita distribution. $80 \%$ of the sample had a GDP per capita level exceeding I\$3,000 in the year 2005.
} 


\section{Results}

\subsection{Cross-sectional estimates}

Results for estimations of equation (1) for each of the nine energy sources for the year-2005 cross-section are presented in Table 2. Specification 1 includes only log GDP per capita; Specification 2 also includes the squared log GDP per capita term. The Specification 1 results indicate that the average income effect is negative and statistically significant for the biomass share of the energy mix and positive and statistically significant for the oil, coal, natural gas, nuclear, waste, and wind shares of the energy mix. Income on average has an insignificant impact on the hydro and geothermal shares of the energy mix in this specification. The results imply that economic development involves a large substitution away from biomass and toward commercial energy forms such as fossil fuels and electricity.

-Table 2 here-

The results for Specification 2 in Table 2 allow for non-monotonicities in the income-energy mix relations. The estimates indicate that the biomass share of the energy mix declines until a per capita GDP level of 2005 I\$41,000, from which point biomass tends to become a larger contributor to total energy use again. A biomass revival has indeed been observed in a number of high-income countries, such as Sweden, which has increasingly used biomass for heating and electricity generation. The results also indicate that the coal and oil shares of the energy mix evolve in an inverse-U shaped manner, with peaks at income levels of $2005 \mathrm{I} \$ 14,000$ and $\$ 17,000$. This is consistent with coal and oil being on the middle rungs of the national-level energy ladder, i.e. countries substitute toward coal and oil as they develop, and then eventually start to substitute toward fuels on even higher rungs of the national-level energy ladder. The other results for Specification 2 do not provide strong support for non- 
monotonicities, and like the results for Specification 1 suggest that the natural gas, nuclear, waste, and wind shares of the energy mix tend to increase as countries develop.

Cross-sectional results including the full set of controls are presented in Table 3. These results are generally similar to those in Table 2, and support the conclusion that higher incomes on average result in a reduction in the biomass share of the energy mix (until very high income levels are reached), an initial increase and then decrease in the oil share of the energy mix, and continued increases in the natural gas, nuclear, waste, and wind shares of the energy mix. The estimated quadratic term in the coal regression is statistically insignificant at the standard levels, implying that the overriding feature of the income-coal relationship is that coal's contribution to total energy tends to increase as per capita incomes increase. The coefficients of determination $\left(R^{2}\right)$ are reasonably high for most of the energy source types. For instance, $66 \%$ of the cross-country variation in the biomass share of the energy mix in 2005 is explained by the variables included in the model.

-Table 3 here-

The results on the control variables provide additional information on the determinants of the energy mix. Countries with larger populations tend to have higher dependence on nuclear power and less dependence on hydro and oil, holding other factors constant. Transition economies tend to be less dependent on biomass, oil, geothermal, and wind energy than otherwise similar countries, and more dependent on coal, natural gas, and nuclear power.

The results on the energy endowment controls are of particular interest. The bold coefficients are the own-resource coefficients and should be expected to be positive, as countries are more 
likely to use a particular energy resource if they have large endowments of that resource (and therefore access to it at relatively low cost). These own-resource coefficients are indeed positive and, with the exception of oil, are statistically significant at the 5\% level or higher. They indicate that forested countries tend to be more dependent on biomass, countries with larger freshwater endowments tend to use more hydro power, countries with larger coal or natural gas endowments are particularly dependent on these energy sources, and countries with large geothermal endowments are more likely to develop geothermal energy.

The cross-resource coefficients should be expected to be generally negative: additional endowments of any particular energy resource are likely to reduce the extent to which a country uses other energy sources. The results on the cross-resource variables indicate that bio-rich countries are indeed statistically less likely to climb off the lowest rung of the national-level energy ladder and switch to hydro power or oil. Similarly, countries with large water or fossil fuel endowments are less likely to have climbed to the upper rungs of the national-level energy ladder (nuclear power and modern renewables).

The estimated income effects are large. They suggest that a country with a per capita income of 2005 I $\$ 10,000$ (e.g. South Africa) sources an additional 30 percentage points of its energy from fossil fuels relative to an otherwise similar country with a per capita income of 2005 I $\$ 2,000$. The estimated endowment effects are also large. They imply, for instance, that Australia sources an additional 42 percentage points of its energy from coal relative to an otherwise similar country with no coal endowments.

The exogeneity of fossil fuel reserves is an issue deserving consideration, as measured reserves may be affected by unobserved factors in the error term, such as economic policies or 
cultural preferences. As a robustness check, I ran estimates using back-dated data on fossil fuel reserves for the year 1971 from Norman (2008). Results are similar using this approach, or using alternative data from the World Resources Institute (2010).

An additional issue of concern is that GDP per capita may be correlated with variables in the error term, which would lead to biased and inconsistent estimates of the income effect on the various energy mix shares. Government policies, for instance, may affect both income and the energy mix. To explore this issue I carried out cross-sectional regressions using the approach of Burke (2010) of instrumenting current GDP per capita with historical GDP per capita. The (unreported) instrumental variable results are generally similar. Country-specific factors that are in the error term of the cross-sectional estimates are controlled for in one of the panel data specifications (the fixed effects specification).

\subsection{Panel estimates}

Panel estimates for the period 1960-2005 using both the between estimator and the fixed effects estimator are shown in Table 4. The between estimator can provide consistent estimates of long-run relationships given standard assumptions about the error term and its relationship with the explanatory variables (Stern, 2010). The fixed effects estimator with year dummies controls for country- and time-specific effects. Country-specific factors may include time-invariant aspects of preferences, policies, institutions, economies, climate, geography, culture, and energy security risks. Time-specific factors may include changes in global energy prices, technologies, and perceptions of nuclear safety and energy security.

-Table 4 here- 
Results using the between estimator are similar to the cross-sectional results, and provide support to the finding that economic development results in a falling biomass share of the energy mix (until high income levels are reached), inverse-U shaped coal and oil shares of the energy mix, and increasing natural gas, nuclear, waste, and wind shares of the energy mix. Panel estimations using the fixed effects estimator with year dummies are generally similar, but differ from the earlier results in several ways. The fixed effects results indicate that the biomass share of the energy mix begins to increase again from income levels of 2005 I $\$ 12,000$, a lower estimate than that obtained in the earlier specifications. The fixed effects results also provide statistically significant evidence of an inverse- $U$ shaped impact of economic development on the hydro share of the energy mix, which sees hydroelectricity increase as a share of the energy mix until income levels equivalent to Honduras' 2005 per capita income of around I $\$ 3,400$, and decrease thereafter. The fixed effects results indicate that the oil share of the energy mix at first increases and then decreases as countries develop, with a lower turning point than in the earlier estimations.

As for the cross-sectional results with the control variables (Table 3), the quadratic term in the coal equation is outside the standard significance levels in the fixed effects specification. The estimate points to an initially increasing and then, from middle-income levels, a decreasing relationship between per capita income and the coal share of the energy mix, although care is required on this finding due to its lack of statistical significance. The fixed effects results continue to provide strong evidence that higher incomes on average see increases in the natural gas, nuclear power, waste, and wind shares of the energy mix.

Taken together, the results support the existence of a national-level energy ladder that countries climb as their per capita incomes increase, and are consistent with the implications 
of the energy transition models of Tahvonen and Salo (2001) and Burke (2010). That the most carbon-intensive energy sources are on the middle rungs of the national-level energy ladder suggests that the relationship between per capita income and the carbon intensity of energy is inverse- $U$ shaped. Evidence of such an inverse $U$ is displayed in Figure 1, which plots the carbon intensity of energy against GDP per capita for the 132 countries for the year 2005 . The size of the data points is weighted by the coal share of the energy mix, demonstrating that the countries in which energy is the most carbon-intensive are also the most dependent on coal. The relationship between income per capita and $\mathrm{CO}_{2}$ emissions is further explored in the next section.

-Figure 1 here-

\section{Application of the national-level energy ladder results to carbon emissions trajectories}

There is an extensive literature on the environmental impact of economic development, much of which has fallen under the banner of testing the EKC hypothesis - the idea that there is an initial increase and then eventual reduction in environmental degradation as economies develop. Most studies conclude against the existence of a globally-common inverse- $U$ relationship for per capita $\mathrm{CO}_{2}$ emissions, although there is evidence of EKC-type downturns in per capita $\mathrm{CO}_{2}$ emissions for specific groups of countries (Burke, in press).

The carbon Kuznets curve studies use data on per capita emissions of $\mathrm{CO}_{2}$ from fossil fuel use (which excludes emissions from other sources such as land use change and the use of biomass). Fossil fuel $\mathrm{CO}_{2}$ emissions per capita can be decomposed as follows:

$$
\mathrm{CO}_{2} \text { per capita }=\frac{\text { Energy use }}{\text { Population }} * \frac{\mathrm{CO}_{2}}{\text { Energy use }}
$$


For an inverse-U relationship between per capita income and $\mathrm{CO}_{2}$ emissions per capita to emerge, an (eventually) decreasing relationship between per capita income and at least one of the two right-hand-side terms in equation (2) is needed. The results on the national-level energy ladder are of specific relevance to the second of these terms (the carbon intensity of energy), as the different energy types have different carbon intensities, and the overall carbon intensity of energy is a weighted average of the carbon intensities of individual energy types. Differences in the nature of the relationship between GDP per capita and $\mathrm{CO}_{2}$ emissions per capita and that between GDP per capita and the carbon intensity of energy have been observed elsewhere (Ang and Liu, 2006), but have not been the focus of much analysis.

Table 5 presents quadratic estimates using the four estimation techniques from Section 6 for each of 1) $\log \mathrm{CO}_{2}$ emissions per capita; 2) $\log$ energy use per capita; and 3) the natural logarithm of the carbon intensity of energy. (Results are similar in random effects specifications, but Hausman tests indicate that the fixed effects estimator is preferred to the random effects estimator for each of the three dependent variables.) The results provide little evidence of an inverse- $U$ relationship between per capita income and per capita emissions of $\mathrm{CO}_{2}$, in line with the standing result in the EKC literature for global samples. Only in the fixed effects estimates is there any evidence in favor of an inverse $U$ with a within-sample turning point for per capita $\mathrm{CO}_{2}$ emissions, although the estimated turning point is at a per capita GDP of 2005 I\$40,000 (a level exceeded by only 7 of the countries in the sample in 2005). The results provide even less evidence in favor of an inverse-U relationship between per capita GDP and per capita energy use. Results using all four of the estimation techniques indicate that higher incomes are associated with higher energy use over relevant income ranges, consistent with the findings of other studies (e.g. Tsurumi and Managi, 2010). 
-Table 5 here-

The estimation results for the carbon intensity of energy provide much stronger evidence of an inverse $\mathrm{U}$. Each of the estimations indicate that the carbon intensity of energy increases as economies develop but then begins to decrease again once per capita incomes reach 2005 I\$9,000-17,000 (varying by estimate). There thus appears to be a strong general trend toward carbonization of energy as economies develop, and then a later decarbonization as economies enter the high-income ranks. These trends are a direct product of changes in energy mix as countries climb the national-level energy ladder. While energy decarbonization is not strong enough to reduce total emissions in the average country, the process of energy decarbonization as countries climb to the upper rungs of the national-level energy ladder is the primary reason why overall $\mathrm{CO}_{2}$ emissions trajectories are often concave in shape.

To inform whether downturns in the carbon intensity of energy use as economies develop are a result of climate change policy or the natural evolution of energy systems, I explored the relationship between income per capita and the carbon intensity of energy use for the crosssection of countries in 1971, well before climate change became widely recognized as an important policy issue. The (unreported) results suggest that the inverse-U relationship between GDP per capita and the carbon intensity of energy use already existed in 1971. This suggests that the decarbonization of energy use as incomes increase is largely a product of automatic changes in energy systems as economies develop (e.g. substitution toward natural gas and nuclear power) rather than climate change-related policy efforts.

As observed in Table 3, fossil fuel-rich countries are less likely to transition to the low-carbon energy sources on the upper rungs of the national-level energy ladder (nuclear power and 
modern renewables). It should consequently be expected that countries with large endowments of fossil fuels are less likely to experience reductions in the carbon intensity of energy at high income levels. Figure. 2 presents regression predictions for sub-samples of both fossil fuel-poor countries and fossil fuel-rich countries. The Figure demonstrates that fossil fuel-poor countries typically experience a large reduction in the carbon intensity of energy as they pass the middle stages of economic development. Fossil fuel-rich countries, on the other hand, experience much more restrained reductions in the carbon intensity of their energy. To my knowledge, this is the first evidence on the role of resource endowments in explaining development-path heterogeneity in the carbon intensity of energy.

-Figure 2 here-

\section{Conclusions}

This paper has presented evidence from a large sample of countries for the years 1960-2005 on the existence of a national-level energy ladder that countries climb as they develop. Economic development typically sees countries switch from biomass toward commercial fossil fuels, and also some hydroelectricity. At high income levels, countries increasingly adopt low-carbon energy sources such as nuclear power and certain modern renewables such as wind power. In terms of carbon emissions, the net effect is that economic development causes an initial carbonization, and a later decarbonization, of the energy system.

The results indicate that not all countries climb the ladder in the same manner, however. Countries with large endowments of any energy source are less likely to continue climbing to higher rungs of the national-level energy ladder. Fossil fuel-rich countries are much less likely 
to adopt nuclear power and modern renewables, and to achieve reductions in the carbon intensity of their energy, as they reach high income levels.

The majority of the world's population lives in countries that are still on the upward slope of the carbon intensity of energy curve, where energy systems are likely to become increasingly dependent on carbon-intensive fossil fuels as per capita incomes increase. The results imply that a doubling of India's 2005 per capita income is likely to involve an increase in the carbon intensity of its energy consumption of up to $45 \%$. Economic expansion in even poorer countries looks set to require a substantial increase in the carbon intensity of energy: a doubling of per capita GDP in the Democratic Republic of the Congo (which is currently reliant on biomass for more than $90 \%$ of its energy) is likely to increase the carbon intensity of its energy by up to $170 \%$. In addition to these increases in the carbon intensity of energy, expanding energy use would place extra pressure on $\mathrm{CO}_{2}$ emissions.

There is some brighter news on China: the results imply that the carbon intensity of China's energy use is likely to reduce over coming years as China begins to reorientate its energy mix toward natural gas, nuclear power, and renewable energy. Yet China's overall energy use and $\mathrm{CO}_{2}$ emissions are likely to continue their upward trajectories for the foreseeable future in a business-as-usual development scenario, despite this likely reduction in the carbon intensity of China's energy consumption.

Efforts to encourage leapfrogging to the lower-carbon energy sources on the upper rungs of the national-level energy ladder (modern renewables, nuclear power, and also natural gas), where appropriate, is one potential means to reduce the magnitudes of the upticks in the carbon intensity of energy and total $\mathrm{CO}_{2}$ emissions expected for many developing countries. 
Carbon pricing and the removal of fossil fuel subsidies would help to facilitate such leapfrogging. There may also be a role for developed countries to provide additional assistance to developing countries to aid their early adoption of low-carbon energy sources and technologies.

The results also draw attention to the formidable challenge of weaning fossil fuel-rich countries off their dependence on carbon-intensive fossil fuels, as even at high income levels these countries tend to remain heavily reliant on fossil fuels for their energy needs. The development of affordable lower-carbon fossil fuel energy technologies is likely to be an indispensible part of an optimal climate change mitigation response. 


\section{Appendix - Variable Descriptions}

Biomass share of energy use: Biomass share of TPES (oil-equivalent, \%). IEA (2007a, 2007b).

Hydro share of energy use: Hydro share of TPES (oil-equivalent, \%). IEA (2007a, 2007b).

Oil share of energy use: Crude oil and petroleum share of TPES (oil-equivalent, \%). IEA (2007a, 2007b).

Coal share of energy use: Coal and peat share of TPES (oil-equivalent, \%). IEA (2007a, 2007b).

Natural gas share of energy use: Natural gas share of TPES (oil-equivalent, \%). IEA (2007a, 2007b).

Nuclear share of energy use: Nuclear share of TPES (oil-equivalent, \%). IEA (2007a, 2007b).

Geothermal share of energy use: Geothermal share of TPES (oil-equivalent, \%). IEA (2007a, 2007b).

Waste share of energy use: Use of waste for energy share of TPES (oil-equivalent, \%). IEA (2007a, 2007b).

Wind share of energy use: Wind share of TPES (oil-equivalent, \%). IEA (2007a, 2007b). 
Log GDP per capita: Natural logarithm of GDP per capita in 2005 international \$ (chain series). Heston et al. (2009).

Log population: Natural logarithm of population (in thousands). Heston et al. (2009).

Log land: Natural logarithm of land area in squared kilometers. World Bank (2009).

Transition economy dummy: 1 for countries classed as transition economies, 0 otherwise.

Development Research Institute (2008).

Forest area (squared kilometers per capita): Land under natural or planted stands of trees of at least 5 meters in situ, excluding trees in agricultural production systems or urban parks and gardens. World Bank (2009). Population data from Heston et al. (2009).

Water resources (thousand cubic meters per capita): Renewable internal freshwater resources (internal river flows and groundwater from rainfall) in thousand cubic meters per capita. Data are for 2002. World Bank (2009). Data for Kuwait and Taiwan are from the World Resources Institute (2009).

Oil reserves (thousand tonnes oil equivalent [ttoe] per capita): Proved reserves of crude oil. U.S. Energy Information Administration [EIA] (2009). BP (2009) conversion factors. Countries for which data are not available are considered to have zero reserves. Population data from Heston et al. (2009). 
Coal reserves (ttoe per capita): Total recoverable coal reserves. U.S. EIA (2009). Converted to ttoe using BP (2009) conversion factors. Countries for which data are not available are considered to have zero reserves. Population data from Heston et al. (2009).

Natural gas reserves (ttoe per capita): Proved reserves of natural gas. U.S. EIA (2009). Converted to ttoe using BP (2009) conversion factors. Countries for which data are not available are considered to have zero reserves. Population data from Heston et al. (2009).

Volcanoes per capita $(* 1,000,000)$ : Number of holocene volcanoes*1,000,000, divided by population. Volcanoes straddling national borders are included in the list of volcanoes of all border countries. Siebert and Simkin (2002). Population data from Heston et al. (2009).

Log carbon dioxide emissions per capita $\left(t \mathrm{CO}_{2}\right)$ : Natural logarithm of carbon dioxide emissions from fossil fuel combustion per capita. IEA (2009). Population data from Heston et al. (2009).

Log energy use per capita (toe): Natural logarithm of TPES per capita. IEA (2007a, 2007b). Population data from Heston et al. (2009).

Log carbon intensity of energy ( $\left(\mathrm{CO}_{2} /\right.$ toe ) : Natural logarithm of carbon dioxide emissions from fossil fuel combustion divided by TPES. IEA (2007a, 2007b, 2009). 


\section{References}

Ang, B.W. and N. Liu (2006), ‘A cross-country analysis of aggregate energy and carbon intensities', Energy Policy 34: 2398-2404.

Barnes, D.F. and W. Floor (1999), 'Biomass energy and the poor in the developing world', Journal of International Affairs 53: 237-259.

Bashmakov, I. (2007), 'Three laws of energy transition', Energy Policy 35: 3583-3594.

BP (2009), Statistical Review of World Energy 2009, London: BP.

Burke, P.J. (2010), 'Income, resources, and electricity mix', Energy Economics 32: 616-626.

Burke, P.J. (In press), 'Climbing the electricity ladder generates carbon Kuznets curve downturns', Australian Journal of Agricultural and Resource Economics.

Development Research Institute (2008), Social Indicators and Fixed Factors, http://www.nyu.edu/fas/institute/dri/dataset/Social\%20Indicators\%20Fixed\%20Factors_7_20 05.x1s.

Grübler, A. (2004), ‘Transitions in energy use', Encyclopedia of Energy 6: 163-177.

Hadjilambrinos, C. (2000), 'Understanding technology choice in electricity industries: A comparative study of France and Denmark', Energy Policy 28: 1111-1126. 
Heltberg, R. (2004), 'Fuel switching: Evidence from eight developing countries', Energy Economics 26: 869-887.

Heston, A., R. Summers, and B. Aten (2009), Penn World Table Version 6.3, University of Pennsylvania: Center for International Comparisons of Production, Income and Prices, http://pwt.econ.upenn.edu/php_site/pwt_index.php.

Honoré, B.E. (1992), ‘Trimmed LAD and least squares estimation of truncated and censored regression models with fixed effects', Econometrica 60: 533-565.

Hosier, R.H. (2004), 'Energy ladder in developing countries', Encyclopedia of Energy 2: $423-435$.

Hosier, R.H. and J. Dowd (1987), 'Household fuel choice in Zimbabwe: An empirical test of the energy ladder hypothesis', Resources and Energy 9: 347-361.

International Energy Agency (2007a), Energy Balances of Non-OECD Countries - Extended Balances, Paris: International Energy Agency.

International Energy Agency (2007b), Energy Balances of OECD Countries - Extended Balances, Paris: International Energy Agency.

International Energy Agency (2009), $\mathrm{CO}_{2}$ Emissions from Fuel Combustion, Paris: International Energy Agency. 
Judson, R.A., R. Schmalensee, and T.M. Stoker (1999), 'Economic development and the structure of the demand for commercial energy', Energy Journal 20: 29-57.

Marcotullio, P.J. and N.B. Schulz (2007), 'Comparison of energy transitions in the United States and developing and industrializing economies', World Development 35: 1650-1683.

Medlock, K.B. III and R. Soligo (2001), 'Economic development and end-use energy demand', Energy Journal 22: 77-105.

Norman, C.S. (2008), 'Rule of law and the resource curse: Abundance versus intensity', Environmental and Resource Economics 43: 183-207.

Schäfer, A. (2005), 'Structural change in energy use', Energy Policy 33: 429-437.

Siebert, L. and T. Simkin (2002), Volcanoes of the World: An Illustrated Catalog of Holocene Volcanoes and their Eruptions, Global Volcanism Program Digital Information Series, GVP3, Washington DC: Smithsonian Institution, http:/www.volcano.si.edu/world/.

Stern, D.I. (2010), 'Between estimates of the emissions-income elasticity', Ecological Economics 69: 2173-2182.

Tahvonen, O. and S. Salo (2001), 'Economic growth and transitions between renewable and nonrenewable energy resources', European Economic Review 45: 1379-1398. 
Tsurumi, T. and S. Managi (2010), 'Decomposition of the environmental Kuznets curve:

Scale, technique, and composition effects', Environmental Economics and Policy Studies 11: $19-36$.

U.S. Energy Information Administration (2009), International Energy Statistics 2009, http://tonto.eia.doe.gov/cfapps/ipdbproject/IEDIndex3.cfm.

World Bank (2009), World Development Indicators, http://go.worldbank.org/U0FSM7AQ40.

World Resources Institute (2009), EarthTrends, http://earthtrends.wri.org/.

World Resources Institute (2010), Climate Analysis Indicators Tool, http://cait.wri.org/. 


\section{Tables}

Table 1. Energy mix by income grouping, 2005

\begin{tabular}{|c|c|c|c|c|c|c|c|c|c|}
\hline & $(1)$ & $(2)$ & (3) & (4) & $(5)$ & (6) & (7) & $(8)$ & (9) \\
\hline & \multicolumn{9}{|c|}{-----------------------> National-level energy ladder ------------------------> } \\
\hline \multicolumn{3}{|c|}{ Percentage share of energy Biomass Hydro } & Oil & Coal & Natural & Nuclear & Geo- & \multicolumn{2}{|c|}{ Waste Wind } \\
\hline \multicolumn{3}{|l|}{ use from... } & & & \multicolumn{2}{|l|}{ gas } & \multicolumn{3}{|l|}{ thermal } \\
\hline Low-income countries & 50.3 & 3.5 & 16.7 & 10.1 & 19.1 & 0.0 & 0.2 & 0.0 & 0.0 \\
\hline Middle-income countries & 14.3 & 2.6 & 27.5 & 33.7 & 19.4 & 1.9 & 0.5 & 0.1 & 0.0 \\
\hline High-income countries & 2.7 & 1.9 & 40.8 & 19.5 & 22.8 & 11.0 & 0.4 & 0.5 & 0.1 \\
\hline World & 9.8 & 2.2 & 34.9 & 25.3 & 20.7 & 6.3 & 0.4 & 0.3 & 0.1 \\
\hline \multirow{2}{*}{\multicolumn{10}{|c|}{$\begin{array}{l}\text { Notes: World Bank country classifications as listed in the World Development Indicators in } \\
2010 \text { are used to classify countries into income groups. Data for } 137 \text { countries are used for }\end{array}$}} \\
\hline & & & & & & & & & \\
\hline \multicolumn{10}{|c|}{ constructing the country group averages. An "other" category making up $0.2 \%$ of world energy use } \\
\hline \multicolumn{10}{|c|}{ is not shown. This category includes energy from solar, tide, wave, ocean, other hydrocarbons and } \\
\hline
\end{tabular}


Table 2. Cross-sectional regression results, 2005

Dependent variable: \% share of energy use

\begin{tabular}{|c|c|c|c|c|c|c|c|c|c|}
\hline & (1) & (2) & (3) & (4) & $(5)$ & (6) & (7) & $(8)$ & (9) \\
\hline & Biomass & Hydro & Oil & Coal & $\begin{array}{l}\text { Natural } \\
\text { gas }\end{array}$ & Nuclear & $\begin{array}{l}\text { Geo- } \\
\text { thermal }\end{array}$ & Waste & Wind \\
\hline \multicolumn{10}{|c|}{$\overline{\text { Specification 1: Linear estimates }}$} \\
\hline \multirow[t]{2}{*}{ Log GDP per capita } & -17.29 & -0.59 & 4.54 & 2.65 & 7.32 & 2.21 & 0.41 & 0.19 & 0.06 \\
\hline & $(1.70)^{* * *}$ & $(0.71)$ & $(1.63)^{* * *}$ & $*(1.01)^{* * *}$ & $(1.56)^{* * *}$ & $(0.55)^{* * *}$ & $(0.52)$ & $(0.05)^{* * *}$ & $(0.03)^{* *}$ \\
\hline$R^{2}$ & 0.52 & 0.00 & 0.06 & 0.03 & 0.14 & 0.10 & 0.01 & 0.13 & 0.06 \\
\hline \multicolumn{10}{|c|}{ Specification 2: Quadratic estimates } \\
\hline \multirow[t]{2}{*}{ Log GDP per capita } & -105.32 & 14.95 & 50.02 & 36.68 & 11.06 & 1.08 & -0.40 & -1.13 & -0.33 \\
\hline & $(19.70)^{* * *}$ & $*(9.62)$ & $(21.46)^{* *}$ & $*(14.15)^{* *}$ & $(20.15)$ & $(6.31)$ & $(5.68)$ & $(0.49)^{* *}$ & $(0.21)$ \\
\hline Log GDP per capita, & 4.96 & -0.88 & -2.56 & -1.92 & -0.21 & 0.06 & 0.05 & 0.07 & 0.02 \\
\hline squared & $(1.06)^{* * *}$ & $(0.57)$ & $(1.20)^{* *}$ & $(0.80)^{* *}$ & $(1.18)$ & $(0.37)$ & $(0.35)$ & $(0.03)^{* *}$ & $(0.01)^{*}$ \\
\hline$R^{2}$ & 0.59 & 0.01 & 0.09 & 0.06 & 0.14 & 0.10 & 0.01 & 0.16 & 0.07 \\
\hline GDP per capita level at & 40,903 & 5,113 & 17,372 & 14,293 & 249 & - & 80 & 1,980 & 1,684 \\
\hline turning point (2005 I\$) & & & & & billion & & & & \\
\hline \multirow[t]{2}{*}{ Type of relationship ${ }^{a}$} & $\mathrm{U}$ & No sig. & Inverse- & Inverse- & Increas- & Increas- & No sig. & Increas- & Increasing \\
\hline & & relatior & & $\mathrm{U}$ & ing & ing & relation & ing & \\
\hline
\end{tabular}

Countries: 132

Notes: $* * * * *$, and $*$ indicate statistical significance at the 1,5 , and $10 \%$ levels respectively. Robust standard errors are in parentheses. Coefficients on constants not reported. Sig. $=$ significant.

${ }^{\text {a }}$ Relationships are only classed as non-linear if the quadratic term is statistically significant at the $10 \%$ level and estimated turning points occur at GDP per capita levels in the range 2005 I\$3,000-72,921. 
Table 3. Cross-sectional regression results with controls, 2005

Dependent variable: $\%$ share of energy use

\begin{tabular}{|c|c|c|c|c|c|c|c|c|c|}
\hline & (1) & (2) & (3) & (4) & (5) & (6) & (7) & (8) & (9) \\
\hline & Biomass & Hydro & Oil & Coal & $\begin{array}{l}\text { Natural } \\
\text { gas }\end{array}$ & Nuclear & $\begin{array}{l}\text { Geo- } \\
\text { thermal }\end{array}$ & Waste & Wind \\
\hline \multicolumn{10}{|c|}{ Specification 1: Linear estimates (controls not shown) } \\
\hline \multirow[t]{2}{*}{ Log GDP per capita } & -18.24 & -0.83 & 4.09 & 3.60 & 7.47 & 3.24 & -0.13 & 0.25 & 0.09 \\
\hline & $(1.65)^{* * *}$ & $(0.61)$ & $(1.67)^{* *}$ & $(0.86)^{* * *}$ & $(1.40)^{* * *}$ & $(0.77)^{* * *}$ & $(0.16)$ & $(0.06) * * *$ & $(0.03)^{* *}$ \\
\hline$R^{2}$ & 0.62 & 0.15 & 0.29 & 0.30 & 0.35 & 0.25 & 0.71 & 0.20 & 0.11 \\
\hline \multicolumn{10}{|c|}{ Specification 2: Quadratic estimates } \\
\hline \multirow[t]{2}{*}{ Log GDP per capita } & -90.25 & 10.21 & 85.89 & 16.12 & -1.85 & -16.26 & 6.90 & -1.87 & -0.48 \\
\hline & \multicolumn{2}{|c|}{$(21.37)^{* * *}(11.20)$} & \multicolumn{2}{|c|}{$(22.81)^{* * *}(10.57)$} & $(15.81)$ & $(6.25)^{* *}$ & $(4.22)$ & $(0.58) * * *$ & $(0.26)^{*}$ \\
\hline Log GDP per capita, & 4.11 & -0.63 & -4.66 & -0.71 & 0.53 & 1.11 & -0.40 & 0.12 & 0.03 \\
\hline squared & $(1.18)^{* * *}$ & $(0.65)$ & $(1.28)^{* * *}$ & $(0.61)$ & $(0.90)$ & $(0.39)^{* * *}$ & $(0.24)$ & $(0.04)^{* * *}$ & $(0.02)^{*}$ \\
\hline \multirow[t]{2}{*}{ Log population } & 1.89 & -2.53 & -3.92 & 2.26 & -0.11 & 1.58 & 0.25 & 0.06 & -0.01 \\
\hline & $(1.55)$ & $(1.14)^{* *}$ & $(1.71)^{* *}$ & $(2.26)$ & $(2.12)$ & $(0.54)^{* * *}$ & $(0.33)$ & $(0.04)$ & $(0.02)$ \\
\hline \multirow[t]{2}{*}{ Log land } & -2.06 & 1.85 & -0.93 & 0.20 & 2.03 & -0.32 & -0.37 & -0.02 & 0.01 \\
\hline & $(1.29)$ & $(0.81)^{* *}$ & $(1.78)$ & $(1.59)$ & $(2.03)$ & $(0.45)$ & $(0.28)$ & $(0.04)$ & $(0.01)$ \\
\hline Transition economy & -12.22 & 1.57 & -24.23 & 9.24 & 19.12 & 6.82 & -1.23 & 0.05 & -0.06 \\
\hline dummy & $(3.83)^{* * *}$ & $(2.84)$ & $(3.99)^{* * *}$ & $(4.68)^{*}$ & $(5.85)^{* * *}$ & $(2.08) * * *$ & $(0.70)^{*}$ & $(0.07)$ & $(0.03)^{*}$ \\
\hline Forest area (squared & 292.05 & -167.19 & -254.55 & 98.10 & -91.76 & 105.33 & -4.57 & 2.91 & -0.73 \\
\hline kilometers per capita) & \multicolumn{4}{|c|}{$(\mathbf{9 8 . 0 1})^{* * *}(73.03)^{* *}(103.16)^{* *}(89.52)$} & $(106.70)$ & \multicolumn{2}{|c|}{$(30.33)^{* * *}(19.15)$} & $(1.93)$ & $(0.86)$ \\
\hline Water resources ('000 & 0.00 & 0.27 & 0.11 & -0.18 & -0.08 & -0.10 & 0.00 & -0.004 & -0.001 \\
\hline cubic meters per capita) & $(0.10)$ & $(0.08) * * *$ & * $(0.09)$ & $(0.11)$ & $(0.10)$ & $(0.03)^{* * *}$ & $(0.02)$ & $(0.002)^{* *}$ & $(0.001)$ \\
\hline Oil reserves (ttoe per & -0.84 & -0.87 & 2.22 & -2.73 & 4.55 & -1.90 & -0.02 & -0.20 & -0.07 \\
\hline capita) & $(0.90)$ & $(0.64)$ & (1.90) & $(1.25)^{* *}$ & $(3.35)$ & $(0.75)^{* *}$ & $(0.13)$ & $(0.07)^{* * *}$ & $(0.04)^{* *}$ \\
\hline Coal reserves (ttoe per & -3.09 & -2.86 & -0.85 & 22.51 & -8.32 & -6.94 & 0.72 & -0.36 & -0.11 \\
\hline capita) & $(5.07)$ & $(3.03)$ & $(7.07)$ & $(8.78) * *$ & $(5.28)$ & $(2.26)^{* * *}$ & $(0.51)$ & $(0.12)^{* * *}$ & $(0.06)^{*}$ \\
\hline Natural gas reserves (ttoe & 0.07 & 0.02 & -1.35 & -0.02 & 1.58 & -0.23 & 0.03 & -0.03 & -0.01 \\
\hline per capita) & $(0.13)$ & $(0.08)$ & $(0.24)^{* * *}$ & $(0.15)$ & $(0.38) * * *$ & $(0.09)^{* *}$ & $(0.02)$ & $(0.01)^{* * *}$ & $(0.005)^{*}$ \\
\hline Volcanoes per capita & 0.07 & -1.38 & -0.95 & 0.93 & 0.14 & 0.49 & 0.55 & 0.02 & 0.00 \\
\hline$(* 1,000,000)$ & $(0.51)$ & $(0.40)^{* * *}$ & $*(0.47)^{* *}$ & $(0.56)^{*}$ & $(0.52)$ & $(0.16)^{* * *}$ & $(0.13)^{* * *}$ & $*(0.01) *$ & $(0.01)$ \\
\hline$R^{2}$ & 0.66 & 0.15 & 0.37 & 0.30 & 0.35 & 0.28 & 0.72 & 0.27 & 0.13 \\
\hline $\begin{array}{l}\text { GDP per capita level at } \\
\text { turning point ( } 2005 \text { I\$) }\end{array}$ & 59,247 & 3,314 & 9,958 & 79,772 & 6 & 1,499 & 5,476 & 2,309 & 1,717 \\
\hline Type of relationship ${ }^{a}$ & $\mathrm{U}$ & $\begin{array}{l}\text { No sig. } \\
\text { relation }\end{array}$ & Inverse-U & $\begin{array}{l}\text { Increas- } \\
\text { ing }\end{array}$ & $\begin{array}{l}\text { Increas- } \\
\text { ing }\end{array}$ & Increasing & $\begin{array}{l}\text { No sig. } \\
\text { relation }\end{array}$ & Increasing & Increasing \\
\hline \multicolumn{10}{|l|}{ Countries: $131^{\mathrm{b}}$} \\
\hline \multicolumn{10}{|c|}{$\begin{array}{l}\text { Notes: }{ }^{* *},{ }^{* *} \text {, and } * \text { indicate statistical significance at the } 1,5 \text {, and } 10 \% \text { levels respectively. Robust standard errors are in } \\
\text { parentheses. Coefficients on constants not reported. The bold diagonal is the set of own-resource coefficients. Sig.= } \\
\text { significant. }\end{array}$} \\
\hline
\end{tabular}


Table 4. Panel data results

Dependent variable: \% share of energy use

\begin{tabular}{|c|c|c|c|c|c|c|c|c|c|}
\hline & $(1)$ & (2) & (3) & (4) & $(5)$ & (6) & (7) & $(8)$ & (9) \\
\hline & Biomass & Hydro & Oil & Coal & Natural gas & Nuclear & $\begin{array}{l}\text { Geo- } \\
\text { thermal }\end{array}$ & Waste & Wind \\
\hline \multicolumn{10}{|c|}{ Panel A: Between estimates } \\
\hline \multicolumn{10}{|c|}{ Specification 1: Linear estimates } \\
\hline $\begin{array}{l}\text { Log GDP per } \\
\text { capita }\end{array}$ & $\begin{array}{l}-20.89 \\
(1.76)^{* * *}\end{array}$ & $\begin{array}{l}-0.08 \\
(0.69)\end{array}$ & $\begin{array}{l}8.41 \\
(1.84)^{* * *}\end{array}$ & $\begin{array}{l}3.30 \\
(1.49)^{* *}\end{array}$ & $\begin{array}{l}7.21 \\
(1.67)^{* * *}\end{array}$ & $\begin{array}{l}1.44 \\
(0.47)^{* * *}\end{array}$ & $\begin{array}{l}0.34 \\
(0.35)\end{array}$ & $\begin{array}{l}0.08 \\
(0.02) * * *\end{array}$ & $\begin{array}{l}0.01 \\
(0.00)^{* *}\end{array}$ \\
\hline$R^{2}$ (between) & 0.52 & 0.00 & 0.14 & 0.04 & 0.13 & 0.07 & 0.01 & 0.12 & 0.03 \\
\hline \multicolumn{10}{|c|}{ Specification 2: Quadratic estimates } \\
\hline $\begin{array}{l}\text { Log GDP per } \\
\text { capita }\end{array}$ & $\begin{array}{l}-117.87 \\
(25.11)^{* * *}\end{array}$ & $\begin{array}{l}12.81 \\
(10.43)\end{array}$ & $\begin{array}{l}93.21 \\
(26.72)^{* * *}\end{array}$ & $\begin{array}{l}40.38 \\
(22.29)^{*}\end{array}$ & $\begin{array}{l}-33.44 \\
(24.93)\end{array}$ & $\begin{array}{l}7.22 \\
(7.10)\end{array}$ & $\begin{array}{l}1.60 \\
(5.32)\end{array}$ & $\begin{array}{l}-0.24 \\
(0.27)\end{array}$ & $\begin{array}{l}-0.01 \\
(0.05)\end{array}$ \\
\hline $\begin{array}{l}\text { Log GDP per } \\
\text { capita, squared }\end{array}$ & $\begin{array}{l}5.58 \\
(1.44) * * *\end{array}$ & $\begin{array}{l}-0.74 \\
(0.60)\end{array}$ & $\begin{array}{l}-4.88 \\
(1.53)^{* * *}\end{array}$ & $\begin{array}{l}-2.13 \\
(1.28)^{*}\end{array}$ & $\begin{array}{l}2.34 \\
(1.43)\end{array}$ & $\begin{array}{l}-0.33 \\
(0.41)\end{array}$ & $\begin{array}{l}-0.07 \\
(0.31)\end{array}$ & $\begin{array}{l}0.02 \\
(0.02)\end{array}$ & $\begin{array}{l}0.00 \\
(0.00)\end{array}$ \\
\hline$R^{2}$ (between) & 0.57 & 0.01 & 0.20 & 0.06 & 0.14 & 0.07 & 0.01 & 0.13 & 0.03 \\
\hline GDP per capits & a 38,518 & 5,615 & 14,037 & 12,838 & 1,269 & 51,216 & 60,882 & 742 & 50 \\
\hline
\end{tabular}

level at turning

point (2005 I\$)

Type of U

No sig. Inverse-U Inverse-U Increasing Increasing

No sig. Increasing Increasing relationship $^{\mathrm{a}}$

relation

relation

\section{Panel B: Fixed effects estimates with year dummies}

Specification 1: Linear estimates

$\begin{array}{llllllllll}\text { Log GDP per } & -3.35 & -0.61 & -3.84 & 1.33 & 4.64 & 1.41 & -0.11 & 0.07 & 0.02 \\ \text { capita } & (1.28)^{* * *} & (0.45) & (2.04)^{*} & (1.53) & (1.54)^{* * *} & (0.61)^{* *} & (0.29) & (0.03)^{* *} & (0.01)^{* *} \\ R^{2} \text { (within) } & 0.16 & 0.03 & 0.18 & 0.25 & 0.30 & 0.20 & 0.03 & 0.19 & 0.06 \\ \begin{array}{l}\text { Specification } \\ \text { 2: }\end{array} & \text { Quadratic } & \text { estimates } & & & & & & & \\ \text { Log GDP per } & -55.82 & 7.29 & 50.71 & 23.74 & -7.66 & -9.04 & -2.61 & -1.21 & -0.28 \\ \text { capita } & (10.26)^{* * *} & (3.73)^{*} & (18.31)^{* * *} & (15.10) & (10.19) & (4.54)^{* *} & (2.58) & (0.39)^{* * *} & (0.15)^{*} \\ \text { Log GDP per } & 2.97 & -0.45 & -3.09 & -1.27 & 0.70 & 0.59 & 0.14 & 0.07 & 0.02 \\ \text { capita, squared }(0.56)^{* * *} & (0.22)^{* *} & (1.09)^{* * *} & (0.91) & (0.60) & (0.26)^{* *} & (0.15) & (0.02)^{* * *} & (0.01)^{*} \\ R^{2} \text { (within) } & 0.27 & 0.03 & 0.22 & 0.27 & 0.31 & 0.21 & 0.04 & 0.22 & 0.07 \\ \text { GDP per capita } 11,894 & 3,437 & 3,639 & 11,453 & 243 & 2,056 & 9,906 & 4,312 & 3,634\end{array}$

level at turning

point (2005 I\$)

Type of U

relationship $^{\mathrm{a}}$

Inverse-U Inverse-U

No sig.

Increasing Increasing

No sig. U

U

Observations: 4,337

relation

relation

Years: 1960-2005

Countries: 132

Notes: $* * *, * *$, and * indicate statistical significance at the 1,5 , and $10 \%$ levels respectively. Standard errors are in parentheses. The standard errors in panel B are robust to heteroscedasticity. Coefficients on constants and year dummies not reported. The within- $R^{2}$ reflects the explanatory power of the GDP per capita terms and the year dummies. Sig.= significant.

${ }^{a}$ Relationships are only classed as non-linear if the quadratic term is statistically significant at the $10 \%$ level and estimated turning points occur at GDP per capita levels in the range 2005 I\$3,000-72,921. 
Table 5. Carbon emissions regression results

\begin{tabular}{|c|c|c|c|c|}
\hline & $(1)$ & $(2)$ & $(3)$ & $(4)$ \\
\hline Specification & Cross-sectio & $\begin{array}{l}\text { Cross-sectiona } \\
\text { with full set of } \\
\text { controls }\end{array}$ & $\begin{array}{l}\text { Between } \\
\text { estimates }\end{array}$ & $\begin{array}{l}\text { Fixed effects } \\
\text { with year } \\
\text { dummies }\end{array}$ \\
\hline \multicolumn{5}{|c|}{ Dependent variable 1: Log carbon dioxide emissions per capita $\left(\mathrm{t} \mathrm{CO}_{2}\right)$} \\
\hline Log GDP per capita & $\begin{array}{l}2.53 \\
(0.55)^{* * *}\end{array}$ & $\begin{array}{l}2.15 \\
(0.57)^{* * *}\end{array}$ & $\begin{array}{l}2.96 \\
(0.93) * * *\end{array}$ & $\begin{array}{l}2.71 \\
(0.59) * * *\end{array}$ \\
\hline Log GDP per capita, squared & $\begin{array}{l}-0.08 \\
(0.03)^{* *}\end{array}$ & $\begin{array}{l}-0.05 \\
(0.03) *\end{array}$ & $\begin{array}{l}-0.10 \\
(0.05)^{*}\end{array}$ & $\begin{array}{l}-0.13 \\
(0.03)^{* * *}\end{array}$ \\
\hline$R^{2}$ & 0.82 & 0.86 & 0.77 & 0.37 \\
\hline $\begin{array}{l}\text { GDP per capita level at turning point } \\
\text { (2005 I\$) }\end{array}$ & $17,569,668$ & $327,100,000$ & $4,971,699$ & 39,919 \\
\hline Type of relationship ${ }^{a}$ & Increasing & Increasing & Increasing & Inverse-U \\
\hline \multicolumn{5}{|c|}{ Dependent variable 2: Log energy use per capita (toe) } \\
\hline Log GDP per capita & $\begin{array}{l}-1.12 \\
(0.41)^{* * *}\end{array}$ & $\begin{array}{l}-1.50 \\
(0.43)^{* * *}\end{array}$ & $\begin{array}{l}-1.07 \\
(0.61)^{*}\end{array}$ & $\begin{array}{l}0.65 \\
(0.49)\end{array}$ \\
\hline Log GDP per capita, squared & $\begin{array}{l}0.11 \\
(0.02)^{* * *}\end{array}$ & $\begin{array}{l}0.13 \\
(0.02)^{* * *}\end{array}$ & $\begin{array}{l}0.11 \\
(0.03)^{* * *}\end{array}$ & $\begin{array}{l}-0.02 \\
(0.03)\end{array}$ \\
\hline$R^{2}$ & 0.84 & 0.88 & 0.78 & 0.46 \\
\hline $\begin{array}{l}\text { GDP per capita level at turning point } \\
\text { (2005 I\$) }\end{array}$ & 150 & 279 & 124 & $1,641,000,000$ \\
\hline Type of relationship ${ }^{a}$ & Increasing & Increasing & Increasing & Increasing $^{\mathrm{c}}$ \\
\hline \multicolumn{5}{|c|}{ Dependent variable 3: $\mathrm{Log}$ carbon intensity of energy $\left(\mathrm{t} \mathrm{CO}_{2} /\right.$ toe $)$} \\
\hline Log GDP per capita & $\begin{array}{l}3.65 \\
(0.55)^{* * *}\end{array}$ & $\begin{array}{l}3.65 \\
(0.58) * * *\end{array}$ & $\begin{array}{l}4.02 \\
(0.61)^{* * *}\end{array}$ & $\begin{array}{l}2.06 \\
(0.35)^{* * *}\end{array}$ \\
\hline Log GDP per capita, squared & $\begin{array}{l}-0.19 \\
(0.03)^{* * *}\end{array}$ & $\begin{array}{l}-0.19 \\
(0.03)^{* * *}\end{array}$ & $\begin{array}{l}-0.21 \\
(0.04)^{* * *}\end{array}$ & $\begin{array}{l}-0.11 \\
(0.02)^{* * *}\end{array}$ \\
\hline$R^{2}$ & 0.51 & 0.57 & 0.53 & 0.20 \\
\hline $\begin{array}{l}\text { GDP per capita level at turning point } \\
\text { (2005 I\$) }\end{array}$ & 16,830 & 16,439 & 16,891 & 9,390 \\
\hline Type of relationship ${ }^{a}$ & Inverse-U & Inverse-U & Inverse-U & Inverse-U \\
\hline Years & 2005 & 2005 & $1960-2005$ & $1960-2005$ \\
\hline Observations & 132 & 131 & 4,337 & 4,337 \\
\hline Countries & 132 & $131^{\mathrm{b}}$ & 132 & 132 \\
\hline
\end{tabular}

Notes: $* * * * *$, and $*$ indicate statistical significance at the 1,5 , and $10 \%$ levels respectively. The full set of controls is those used in Table 3. Standard errors are in parentheses. The standard errors in columns 1, 2, and 4 are robust to heteroscedasticity. Coefficients on constants, year dummies, and controls not reported. $R^{2}$ is the within$R^{2}$ for the fixed effects estimates and the between $-R^{2}$ for the between estimates. The within- $R^{2}$ reflects the explanatory power of the GDP per capita terms and the year dummies.

${ }^{a}$ Relationships are only classed as non-linear if the quadratic term is statistically significant at the $10 \%$ level and estimated turning points occur at GDP per capita levels in the range 2005 I\$3,000-72,921.

${ }^{\mathrm{b}}$ Hong Kong is excluded due to missing resource data.

${ }^{\mathrm{c}}$ The two GDP per capita terms are individually insignificant, but an $F$ test indicates that they are jointly significant. 
Figures

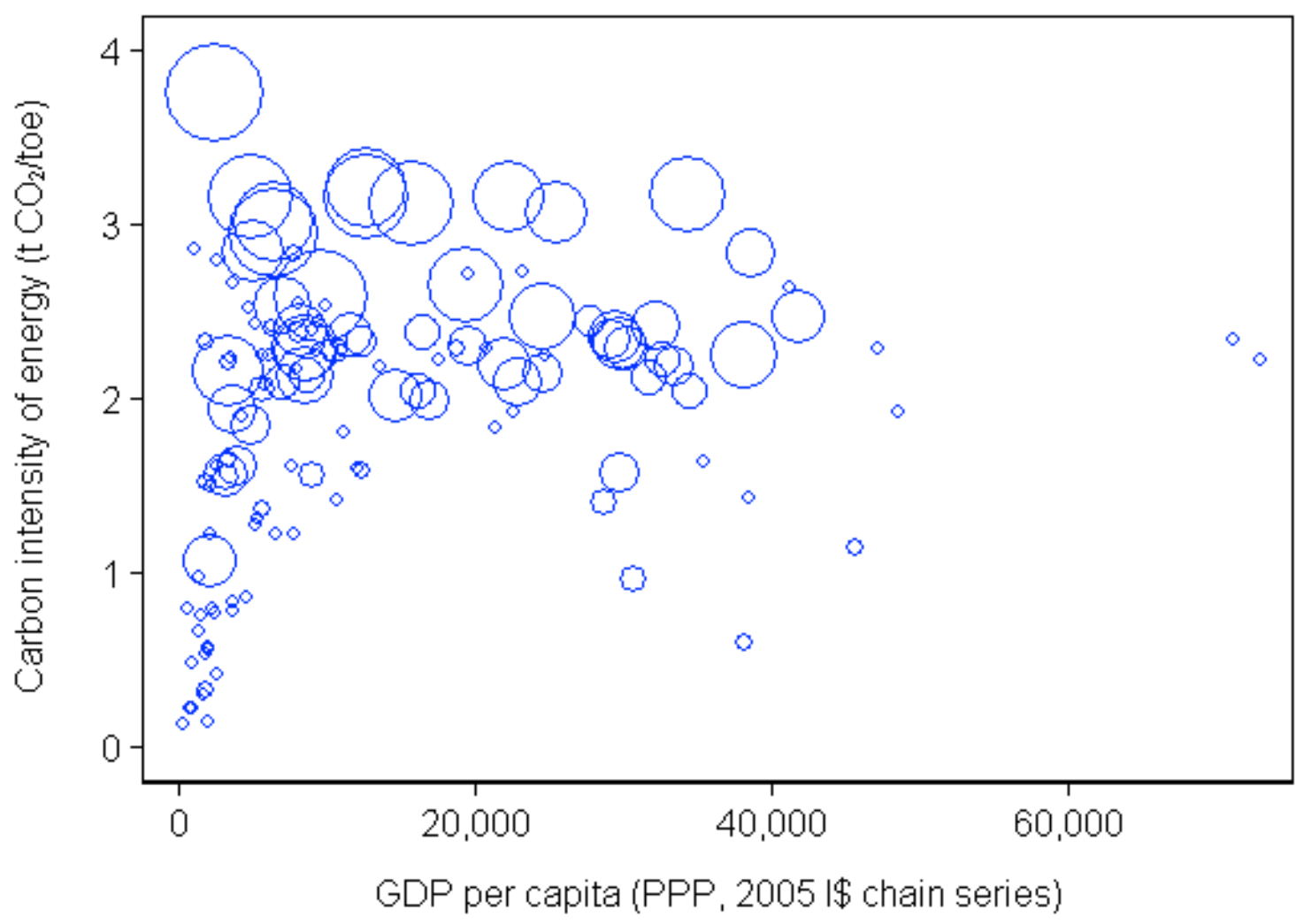

Figure 1. Income and the carbon intensity of energy, 2005

Notes: 132 countries. Marker size is weighted by the coal share of total energy use. 


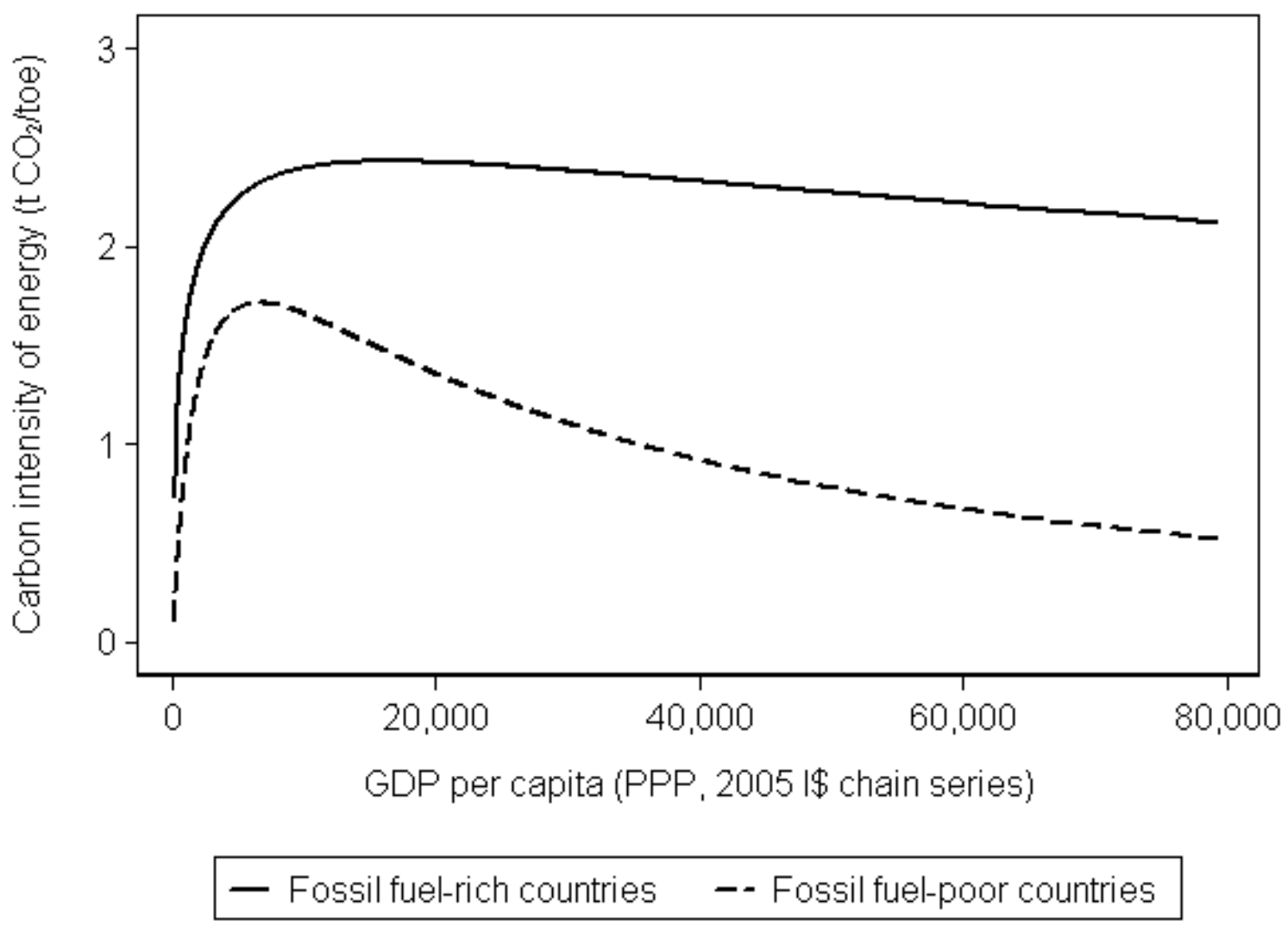

Figure 2. Predicted carbon intensity of energy for fossil fuel-rich and fossil fuel-poor countries

Notes: Uses predictions from quadratic estimations using 1960-2005 fixed effects panel data and controlling for year dummies (i.e. regressions of the sort used in column 4 of Table 5) for countries with above-median and below-median year-2005 fossil fuel reserves. 